\title{
Analisis Pengaruh Pelayanan C2C E-Commerce Bukalapak.com terhadap Kepuasan Konsumen Mahasiswa Perguruan Tinggi Negeri di Kota Jambi
}

\author{
G.W.I Awal Habibah \& Dwi Rizky Ananda \\ Fakultas Ekonomi dan Bisnis Islam UIN Sulthan Thaha Saifuddin Jambi \\ email: getwisdom.insight@gmail.com
}

\begin{abstract}
Abstrak: Penelitian yang melatari tulisan ini bertujuan untuk mengetahui pengaruh pelayanan dalam C2C e-commerce pada Bukalapak.com terhadap kepuasan konsumen. Metode yang digunakan dalam penelitian yaitu metode kuantitatif deskriptif dengan pengumpulan data melalui wawancara, dokumentasi dan angket. Data-data diuji kelayakannya dengan uji validitas dan uji reliabilitas. Kemudian selanjutnya dianalisis dengan uji $t$, regresi sederhana, koefisien determinasi. Keseluruhan sampel dalam penelitian ini berjumlah 100 orang. Hasil yang diperoleh adalah pelayanan terbukti berpengaruh signifikan terhadap kepuasan, dengan nilai sig $<0,05$. Sehingga hipotesis terbukti baik secara teoritis dan statistik. Selanjutnya, persamaan regresi linier sederhana untuk pengaruh pelayanan terhadap kepuasan konsumen adalah kepuasan $=-0,901+$ 0,817 (kepuasan konsumen). Nilai koefisien determinasinya adalah 0,439. Hasil ini menunjukkan bahwa variabel pelayanan (X) mampu menggerakkan (menjelaskan) variabel kepuasan konsumen sebesar 43,9\%. Sedangkan sisanya 56,1\% nilai kepuasan konsumen dipengaruhi atau dijelaskan oleh faktor-faktor lain yang tidak diteliti dalam penelitian ini.
\end{abstract}

Kata-kata Kunci: Pelayanan, Kepuasan Konsumen, Bukalapak.com

\section{Pendahuluan}

Teknologi informasi telah membuka mata dunia akan sebuah dunia baru dan sebuah jaringan bisnis dunia yang tanpa batas. Disadari bahwa perkembangan teknologi yang disebut internet, telah mengubah pola hidup masyarakat yaitu: interaksi bisnis, ekonomi, sosial dan budaya. Semakin meningkatnya minat masyarakat menggunakan internet, maka semakin besar peluang pemanfaatan internet sebagai sarana atau media pemasaran dan bisnis.Internet telah memunculkan alternatif strategi pemasaran yang baru.Bahkan internet telah memberikan kemungkinan menjadi pasar karena kemampuannya menjadi tempat transaksi. ${ }^{1}$ Berikut tabel yang memperlihatkan pertumbuhan penggunaan internet di Indonesia tahun 2014-2016. ${ }^{2}$

\footnotetext{
${ }^{1}$ Wahana Komputer, Promosi Efektif dengan Web, (Yogyakarta: ANDI), 2003, hlm.132.

${ }^{2} \mathrm{http}$ ///www.apjii.or.id/Hasil-Survei-Penetrasi-dan-Perilaku-Pengguna-Internet Indonesia
} 
Tabel 1.1

Pertumbuhan pengguna internet di Indonesia

\begin{tabular}{|c|c|}
\hline Tahun & Jumlah Pengguna \\
\hline 2014 & 88,1 Juta \\
\hline 2015 & 110,2 Juta \\
\hline 2016 & 132,7 Juta \\
\hline
\end{tabular}

Menurut data pada Asosiasi Penyelenggaraan Jasa Internet Indonesia (APJII)diatas mencatat angka pertumbuhan pengguna internet di Indonesia pada tahun 2015 mencapai 110,2 juta orang. Sedangkan untuk wilayah kota Jambi pertumbuhan penggunaan internet dapat dilihat pada tabel berikut:

Tabel 1.2

Data Pengguna Internet di Provinsi Jambi

\begin{tabular}{|c|l|c|}
\hline No. & \multicolumn{1}{|c|}{ Nama Kabupaten/Kota } & Jumlah Pengguna \\
\hline 1. & Kabupaten Batanghari & 84.000 \\
\hline 2. & Kabupaten Bungo & 114.000 \\
\hline 3. & Kabupaten Kerinci & 90.000 \\
\hline 4. & Kabupaten Merangin & 122.400 \\
\hline 5. & Kabupaten Muaro Jambi & 148.800 \\
\hline 6. & Kabupaten Sarolangun & 99.600 \\
\hline 7. & Kabupaten Tanjung Jabung Barat & 104.400 \\
\hline 8. & Kabupaten Tanjung Jabung Timur & 72.000 \\
\hline 9. & Kabupaten Tebo & 86.400 \\
\hline 10. & Kota Jambi & 212.400 \\
\hline 11. & Kota Sungai Penuh & 66.000 \\
\hline
\end{tabular}

Sumber: APJII (Asosiasi Penyelenggara Jasa Internet Indonesia)

Pada tabel diatas dapat dilihat bahwa kota Jambi merupakan kabupaten/kota dengan jumlah pengguna terbanyak dengan jumlah 212.400 orang. Dilihat dari pemanfaatan internet di bidang ekonomi menunjukkan bahwa $32,19 \%$ digunakan untuk kegiatan pembelian online. ${ }^{3}$

Fenomena ini tentu saja menjadi peluang bisnis bagi beberapa pihak yang kemudian menangkap peluang tersebut dengan menyediakan atau membuat online shop sebagai bagian dari e-commerce.E-commerce merupakan kegiatan bisnis yang menyangkut konsumen (consumers), manufaktur (manufactures), service providers dan pedagang perantara (intermediaries) dengan menggunakan jaringan komputer (computer networks) yaitu internet. ${ }^{4}$

\footnotetext{
${ }^{3}$ http://www.apjii.or.id/Hasil-Survei-Penetrasi-dan-Perilaku-Pengguna-InternetIndonesia

${ }^{4}$ Abdullah Halim Barkatullah dan Teguh Prasetyo, Bisnis E-commerce Studi Sistem

Keamanan Dan Hukum Di Indonesia, (Yogyakarta : Pustaka Pelajar), 2005, hlm.10
} 
Salah satu layanan bisnis e-commerce yang populer adalah Consumer-toConsumer (C2C) yang merupakan jenis e-commerce meliputi semua transaksi elektronik barang atau jasa antar konsumen.Umumnya transaksi ini dilakukan melalui pihak ketiga yang menyediakan platform online untuk melakukan transaksi tersebut.Salah satu contoh situs jual beli online yang berbasis C2C di Indonesia adalah Bukalapak.com dimiliki dan dikelola oleh PT. Bukalapak, Bukalapak.com menyediakan sarana penjualan dari konsumen ke konsumen dimanapun dan siapapun dapat membuka toko online untuk melayani calon pembeli dari seluruh Indonesia.Dengan fasilitas yang dimiliki Bukalapak.com seperti fitur nego menjadi suatu daya tarik sendiri bagi para pengguna online shop. Hal ini tidak menutup kemungkinan bagi para pengguna internet akan menggunakan layanan Bukalapak.com.

Mahasiswa perguruan tinggi negeri Universitas Jambi dan Universitas Islam Negeri Sulthan Thaha Saifuddin Jambi dipilih menjadi subjek penelitian karena hampir semua mahasiswa menggunakan aplikasi baik untuk sosialisasi maupun belanja online. Selain itu, dua perguruan tinggi negeri tersebut dipilih karena merupakan perguruan tinggi negeri terbesar di kota Jambi.

Dari hasil wawancara dengan salah satu mahasiswa yang pernah berbelanja di Bukalapak.com, beranggapan bahwa berbelanja secara online lebih praktis tanpa harus ke toko-toko. Tidak perlu dirugikan dengan macetnya lalu lintas, mengunjungi toko satu ke toko lain untuk mencari atau membandingkan harga dan merk. Dengan situs Bukalapak.com, konsumen dapat dengan leluasa membandingkan barang kapanpun dan dimanapun tanpa menghabiskan waktu dan tenaga. ${ }^{5}$

Tabel dibawah ini memperlihatkan top brand situs jual beli online di Indonesia tahun 2014-2016: 6

Tabel 1.3

Top Brand Tahun 2014

SITUS JUAL BELI ONLINE

\begin{tabular}{|l|l|l|}
\hline MEREK & TBI & TOP \\
\hline OLX.co.id & $21.6 \%$ & TOP \\
\hline Berniaga.com & $1.2 \%$ & \\
\hline Tokopedia.com & $1.2 \%$ \\
\hline Kaskus.co.id & $0.9 \%$ \\
\hline Bukalapak.com & $0,7 \%$ \\
\hline
\end{tabular}

\footnotetext{
${ }^{5}$ Hasil wawancara dengan Habibi, mahasiswa fakultas ekonomi dan bisnis jurusan manajemen Universitas Jambi.

${ }^{6}$ www.topbrand-award.com
} 
Tabel 1.4

Top Brand Tahun 2015

SITUS JUAL BELI ONLINE

\begin{tabular}{|l|l|l|}
\hline MEREK & TBI & TOP \\
\hline OLX.coid & $21.6 \%$ & TOP \\
\hline Berniaga.com & $1.2 \%$ & \\
\hline Tokopedia.com & $1.2 \%$ \\
\hline Kaskus.co.id & $0.9 \%$ & \\
\hline Bukalapak.com & $0.7 \%$ \\
\hline
\end{tabular}

Tabel 1.5

Top Brand Tahun 2016

SITUS JUAL BELI ONLINE

\begin{tabular}{|l|l|l|}
\hline MEREK & TBI & TOP \\
\hline OLX.co.id & $44.5 \%$ & TOP \\
\hline Lazada.co.id & $19.9 \%$ & TOP \\
\hline Tokopedia.com & $12.1 \%$ & TOP \\
\hline Bukalapak.com & $11.8 \%$ & \\
\hline Elevania.co.id & $1.6 \%$ & \\
\hline
\end{tabular}

Berdasarkan data Top Brand Award pada tahun 2014-2016 dapat diketahui bahwa bukalapak.com pada tahun 2014-2015 berada diperingkat terakhir yaitu 5 dengan TBI yang sama yaitu hanya sebesar 0,7\%, sedangkan pada tahun 2016 bukalapak.com naik ke peringkat 4 dengan TBI sebesar 11,8\%. Melihat dari perkembangan data diatas menunjukkan bahwa bukalapak.com masih kalah dengan situs jual beli online lainnya. Hal ini menunjukkan bahwa pentingnya kepuasan konsumen (costumer satisfaction) agar bukalapak.com bisa lebih unggul dari situs jual beli online lainnya.Hal ini dapat dipengaruhi oleh pelayanan.

Berdasarkan penelitian sebelumnya dari Yuda Syahidin dan Mira Veranita (2014) meneliti tentang Penerapan Teknologi E-commerce dalam Bisnis Penjualan Produk Secara Online (Studi Pada PT Sakura Bandung) menyimpulkan bahwa dengan menerapkan e-commerce dalam menjual produk dapat memperoleh beberapa keuntungan yang meliputi layanan konsumen dan pencitraan suatu perusahaan menjadi lebih baik serta menemukan partnership, proses efisiensi waktu, peningkatan produktivitas efisiensi dalam biaya dan yang lebih pentingnya fleksibilitas bertambah. ${ }^{7}$ Firza Rizqulloh dan Tety Elida (2015) meneliti tentang

${ }^{7}$ Yuda Syahidin, Mira Veranita,Penerapan Teknologi e-commerce dalam bisnis penjualan produk secara online (studi pada PT Sakura Bandung), (2014),Vol.9 No.1, hlm.15, Lihat pada 
Pengaruh Kualitas Pelayanan, Word of Mouth, dan Loyalitas Pelanggan terhadap Niat Pembelian Kembali Pada BukaLapak.com menyimpulkan bahwa kualitas pelayanan tidak mempunyai pengaruh yang signifikan tehadap niat pembelian kembali pada bukalapak.com. ${ }^{8}$

Usaha yang bergerak di bidang bisnis selalu berusaha untuk terus menerus memberikan kepuasan pada konsumen, karena kepuasan konsumen merupakan tolak ukur dari intensitas konsumen dan telah di akui sebagai salah satu poin utama penyebab loyalitas konsumen.

Berdasarkan penjelasan di atas, dapat disimpulkan bahwa permasalahan mendasar yaitu apakah melalui pelayanan dapat berpengaruh untuk meningkatkan kepuasan konsumen bukalapak.com. Tulisan ini akan mendalami apakah pelayanan dalam Bukalapak.com berpengaruh terhadap kepuasan konsumen dan daya beli mereka.

\section{Pelayanan dan Kepuasan Pelanggan}

Dari hasil penelitian ini pelayanan berpengaruh signifikan terhadap kepuasan konsumen berbelanja di bukalapak.com. Maka dari hasil tersebut dapat dikatakan bahwa pelayanan merupakan salah satu faktor yang tidak dapat dipisahkan dari kepuasan konsumen saat melakukan pembelanjaan online. Pelayanan merupakan hal pertama yang akan dirasakan oleh konsumen saat akan berbelanja, hal inilah yang akan jadi penentu kepuasan konsumen apakah pelayanan yang diberikan sesuai harapan konsumen, melebihi, atau bahkan tidak sesuai yang diharapkan konsumen.

"Pembeli adalah Raja" merupakan jargon dalam bisnis yang sering kita dengar. Pembeli diperlakukan seperti raja yang memiliki makna bahwa pembeli harus mendapatkan pelayanan yang sangat baik dari penjual. Jika pembeli merasa tidak mendapatkan pelayanan yang baik dari penjual, maka pembeli tersebut akan berpindah kepada penjual lain. Penjual yang tidak melayani pembelinya dengan baik, mereka akan kehilangan konsumennya. Setiap penyelenggara pelayanan perlu melakukan perbaikan kualitas layanan dari waktu ke waktu. Terlebih bagi penyelenggaraan pelayanan yang hidup dalam lingkungan persaingan yang sangat ketat dan tuntutan pelayanan oleh masyarakat yang tinggi.Perbaikan terhadap kualitas layanan kepada konsumen (pengguna) adalah mutlak harus dilakukan oleh organisasi, baik organisasi bisnis maupun non bisnis. ${ }^{9}$

Harapan konsumen terhadap pelayanan merupakan keinginan atau permintaan ideal konsumen terhadap pelayanan yang akan diberikan oleh penyedia layanan. Harapan konsumen harus menjadi acuan bagi penyedia layanan untuk mendesain, menghasilkan, dan menyampaikan layanan kepada konsumen.Harapan konsumen pada dasarnya dipengaruhi oleh faktor komunikasi antar mulut ke mulut (word of mouth), kebutuhan, individu konsumen (personal

http://www.academia.edu/34716978/penerapan_teknologi_e-

commerce_dalam_bisnis_penjualan_produk_secara_online_Studi_Kasus_PT_Sakura_Bandung

${ }^{8}$ Firza Rizqulloh, Tety Elida, Pengaruh Kualitas Pelayanan, Word of Mouth, dan Loyalitas

Pelanggan terhadap Niat Pembelian Kembali Pada BukaLapak.com. Jurnal Universitas Gunadarma,(2015), Vol.20 No.2, hlm.11.

${ }^{9}$ Algifari, opcit, hlm.1-2 
needs), dan pengalaman yang dirasakan oleh konsumen pada masa lalu (past experoence). ${ }^{10}$

Dari hasil wawancara dengan mahasiswi mengatakan bahwa awalnya ia berbelanja di bukalapak.com karena adanya pembicaraan mulu ke mulut (word of mouth) atau rekomendasi dari temannya yang sering berbelanja di bukalapak.com, yang mengatakan bahwa bukalapak.com melakukan pelayanan dengan baik dan tidak pernah terjadi penipuan atau barang yang dibeli berbeda dengan yang dijual selama ia berbelanja disana. Hal itulah yang membuatnya juga tertarik berbelanja di bukalapak.com, dan selama berbelnja di buklapak.com merasakan puas dengan layanan yang diberikan. ${ }^{11}$

Kualitas yang dirumuskan oleh penyedia pelayanan harus dimulai dari kebutuhan penggunaan pelayanan dan berakhir pada persepsi pengguna pelayanan.Dengan demikian, citra kualitas pelayanan yang baikbukan hanya didasarkan pada perspektif pihak penyedia pelayanan saja, namun didasarkan juga pada perspektif pihak yang mengkonsumsi dan menikmati pelayanan, sehingga seharusnya mereka menentukan kualitas pelayanan.Persepsi penggunaan pelayanan terhadap kualitas pelayanan merupakan penilaian menyeluruh atats keunggulan suatu pelayanan. Faktor-faktor yang berpengaruh terhadap persepsi pengguna pelayanan atas suatu pelayanan adalah cara penyampaian pelayanan (service encounters), bukti pelayanan (evidence of service), citra perusahaan (image), dan harga pelayanan (price of services).

Memberikan pelayanan terbaik kepada umat manusia adalah pekerjaan yang sangat mulia dan merupakan pintu kebaikan bagi siapa saja yang mau melakukannya. Allah berfirman dalam potongan surat Al-Maidah ayat dua yang berbunyi:

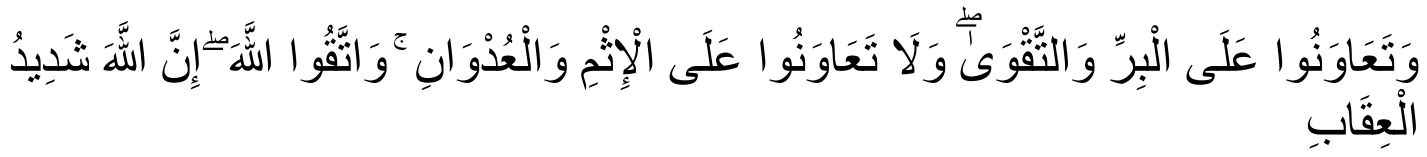

Artinya: Dan tolong-menolonglah kamu dalam hal (mengerjakan) kebaikan dan taqwa, dan janganlah kamu tolong-menolong dalam berbuat dosa dan pelanggaran. Dan bertaqwalah kamu kepada Allah, sesungguhnya Allah amat berat menyiksaNya. ${ }^{12}$

Melalui ayat diatas, Allah memerintahkan kepada kita untuk saling menolong dalam koridor "mengerjakan kebajikan dan takwa" dan Allah melarang sebaliknya. Jika kita melanggar ketentuan Allah maka hukuman akan diberikan dan "Sesungguhnya Allah amat berat siksa-Nya". Jadi interaksi itu bias dilakukan kapanpun dan dengan siapapun selama tidak melanggar batasan diatas.

Jadi, pelayanan merupakan suatu perbuatan yang sangat mulia. Hal tersebut menunjukkan perbuatan yang baik dan siapa saja yang berbuat, maka ia akan mendapatkan pahala dari Allah SWT.

\footnotetext{
${ }^{10}$ Algifari, opcit, hlm.123-124

${ }^{11}$ Hasil wawancara dengan Rafika, mahasiswi fakultas hukum Universitas Jambi, Jambi.

${ }^{12}$ QS. Al-Maidah (5): 2
} 


\section{Penutup}

Dari hasil penelitian ini dapat disimpulkan bahwa pelayanan berpengaruh signifikan terhadap kepuasan konsumen berbelanja di bukalapak.com. Maka dari hasil tersebut dapat dikatakan bahwa pelayanan merupakan salah satu faktor yang tidak dapat dipisahkan dari kepuasan konsumen saat melakukan pembelanjaan online. Hasil yang diperoleh adalah pelayanan terbukti berpengaruh signifikan terhadap kepuasan, dengan nilai sig $<0,05$. Sehingga hipotesis terbukti baik secara teoritis dan statistik. Selanjutnya, persamaan regresi linier sederhana untuk pengaruh pelayanan terhadap kepuasan konsumen adalah kepuasan $=-0,901+$ 0,817 (kepuasan konsumen). Nilai koefisien determinasinya adalah 0,439. Hasil ini menunjukkan bahwa variabel pelayanan (X) mampu menggerakkan (menjelaskan) variabel kepuasan konsumen sebesar 43,9\%. Sedangkan sisanya 56,1\% nilai kepuasan konsumen dipengaruhi atau dijelaskan oleh faktor-faktor lain yang tidak diteliti dalam penelitian ini.

\section{BIBLIOGRAFI}

Abdullah Halim Barkatullah, Teguh Prasetyo, Bisnis E-commerce Studi Sistem Keamanan Dan Hukum Di Indonesia, (Yogyakarta: Pustaka Pelajar, 2005)

Achmad Andriyanto, Dany Nugroho, Pengaruh Kualitas Layanan terhadap Kepuasan Pelanggan (studi kasus: ABC.COM), Jurnal Politeknik Pos Indonesia, (2016)

Algifari, Mengukur Kualitas Layanan dengan Indeks Kepuasan, Metode ImportancePerformance Analysis (IPA) dan Model Kano, (Yogyakarta: BFE, Cet.1, 2016)

Dewi Nur Setiyaningsih dan D.Koeshatono,PengaruhKepuasan dan Kepercayaan Konsumen terhadap Loyalitas Konsumen dengan Switching Cost Sebagai Variabel Mediasi, Jurnal Universitas Atma Jaya Yogyakarta, (2014)

Eva Melita Fitria, Dampak Online Shop di Instagram dalam Perubahan Gaya Hidup Konsumtif Perempuan Shopaholic di Samarinda, Jurnal Ilmu Komunikasi, (2015)

Firza Rizqulloh dan Tety Elida,Pengaruh Kualitas Pelayanan, Word of Mouth, dan Loyalitas Pelanggan terhadap Niat Pembelian Kembali Pada BukaLapak.com,Jurnal Universitas Gunadarma,(2015)

Galeh Kusuma Denni, Analisis Pengaruh Penerapan E-commerce dan Kualitas Pelayanan terhadap Kepuasan Konsumen Pada PT Armineka Perdana, Jurnal Binus University

Hendrian Pratama Putra, Astri Wulandari, Pengaruh Penerapan E-commerce terhadap Keputusan Pembelian (Studi pada pengguna steam valve), Jurnal Manajemen Pemasaran Universitas Telkom, (2015)

J. Supranto, Pengukuran Tingkat Kepuasan Pelanggan, (Jakarta: Rineka Cipta, Cet.2, 2011) 
Januar Efendi Panjaitan, Pengaruh Kualitas Pelayanan terhadap Kepuasan Pelanggan Pada JNE Cabang Bandung, Jurnal Universitas Telkom, Fakultas Komunikasi dan Bisnis, Vol.11 No.2,(2016)

Jumiyati dan Christiawan Hendratmoko, Pengaruh Kualitas Pelayanan Terhadap Kepuasan Konsumen Di Indomaret Tawangsari Sukoharjo, Jurnal STIE Surakarta, Vol.33, (2014)

Melati Antamas, Pengaruh Pertumbuhan Ekonomi Dan Indeks Pembangunan Manusia Terhadap Tingkat Pengangguran Dan Kemiskinan Di Indonesia, Tulisan: Fakultas Ekonomi Dan Bisnis, Universitas Jambi, (2016)

Melfa Yola dan Duwi Budianto,Analisis Kepuasan Konsumen terhadap Kualitas Pelayanan dan Harga Produk Pada Supermarket dengan Menggunakan Metode Importance Performance Analysis (IPA), Jurnal Optimasi Sistem IndustriUIN Sultan Kasim Riau, Vol.12 No.12,(2013)

Prasetyo Agus Nurrahmanto, Pengaruh Kemudahan Penggunaan, Kenikmatan Berbelanja, Pengalaman Berbelanja dan Kepercayaan Konsumen terhadap Minat Beli Konsumen di Situs Jual Beli Online BukaLapak, Tulisan Universitas Diponegoro Semarang,(2015)

Sebti Atul Awaliyah, Saino, Pengaruh Kualitas Layanan terhadap Kepuasan Pelanggan Online (Studi pada Dkpop Shop), Jurnal Universitas Negeri Surabaya, (2014)

Sirhan fikri, dkk, Pengaruh Kualitas Pelayanan terhadap Kepuasan dan Loyalitas Mahasiswa Studi pada mahasiswa S1 FISIP Universitas Merdeka Malang, Jurnal Bisnis dan Manajemen, Vol.3 No.1,(2016)

Siti Maryama,PenerapanE-commerce dalam Meningkatkan Daya Saing Usaha, Jurnal STIE Ahmad Dahlan, Vol.2 No.1, (2013)

Yuda Syahidin dan Mira Veranita,Penerapan Teknologi e-commerce dalam bisnis penjualan produk secara online (studi pada PT Sakura Bandung), Vol.9 No.1,(2014)

https://id.wikipedia.org/wiki/Bukalapak

http://ridwan202.wordpress.com/2013/02/11/kualitas-pelayanan-dalam-islam/

http://www.apjii.or.id/Hasil-Survei-Penetrasi-dan-Perilaku-Pengguna-InternetIndonesia-

http://www.progresstech.co.id/blog/jenis-e-commerce/

http://www.statista.com/data-pengguna-e-commerce-di-indonesia/html

http://www.statistikian.com/2016/01/uji-asumsi-klasik-regresi-linearspss.html/amp 